\title{
Temporal variations of Temperature, Salinity and circulation in the Peruípe River Estuary
} (Nova Viçosa, BA)

Fernando Pinheiro Andutta ${ }^{(1,2,3)}$, Luiz Bruner de Miranda ${ }^{(1)}$; Carlos Augusto França Schettini ${ }^{(4)}$; Eduardo Siegle $^{(1)}$; Mario Pereira da Silva ${ }^{(5)}$; Vitor Massaki Izumi ${ }^{(1)}$ Felipe Murai Chagas $^{(1)}$.

${ }^{(1)}$ Instituto Oceanográfico - Universidade de São Paulo (IOUSP).

e-m: andutta@usp.br; bruner@usp.br; esiegle@usp.br; vitor@saltambiental.com.br

${ }^{(2)}$ School of Physical, Environmental and Mathematical Sciences, University of New South Wales of Australian Defence Force Academy (UNSW-ADFA), ACT 2600, Australia. e-m: f.andutta@adfa.edu.au

${ }^{(3)}$ School of Engineering and Physical sciences, James Cook University, Townsville QLD 4811, Australia.

e-m: fernando.andutta@my.jcu.edu.au

${ }^{(4)}$ Departamento de Oceanografia - Universidade Federal de Pernambuco (DOcean/UFPE) e-m: carlos.schettini@pq.cnpq.br

${ }^{(5)}$ Universidade Federal do Rio Grande do Norte (DGEF-UFRN) - Departamento de Geofísica e-mail: mariop@geofisica.ufrn.br

\begin{abstract}
Eulerian profiles of thermohaline properties and currents have been sampled in the Peruípe River Estuary (Nova Viçosa, BA), southern region of the Caravelas-Peruípe Rivers Estuarine System. One station was located near the mouth (C) and other one up the estuary (E). The Hansen-Rattray diagram classification of the upper reaches of the Peruípe river estuary in the wet season changed from Type $2 \mathrm{~b}$ (partially mixed and highly stratified $-v=0.88$ ) to Type $1 \mathrm{~b}$ (highly stratified $v \sim 1.00)$ due to the fortnightly tidal modulation. This region was mainly forced by river discharge $\left(\mathrm{Ri}_{\mathrm{E}}=5.7\right.$ and $\left.\mathrm{Ri}_{\mathrm{E}}=4.1\right)$ and characterized by high $\left(\mathrm{Ri}_{\mathrm{L}}>20\right)$ and low stabilities $\left(\mathrm{Ri}_{\mathrm{L}}<20\right)$ in the neap and spring tidal cycles. However, near the mouth stratification was strongly modulated by the tide, and its classification alternates from being highly stratified (Type $2 b-v=0.92$ ) in the neap tide to being well mixed with low stratification (Type 1a $-v=1.00$ ); the mouth was dominated by fresh water discharge $\left(\mathrm{Ri}_{\mathrm{E}}=12.9\right)$ and tidal stirring $\left(\mathrm{Ri}_{\mathrm{E}}=0.6\right)$ in the neap and spring tide, respectively, and were associated with high and low stabilities. The classical steady-state salinity and velocity profiles show good agreement (Skill 1.0) with the corresponding observational profiles when simulated with
\end{abstract}


a classical analytical model. The main characteristics of the nearly steady-state bidirectional (with a weak barolinic signal) and unidirectional velocity profiles were in good agreement with the estuarine quantitative classifications (Types $2 b, 1 a$ and $1 b$ ). The rate of change of the potential energy due to fortnightly tidal modulation was slightly higher near the mouth $\left(6.1 \mathrm{~J} \mathrm{~m}^{-3} \mathrm{~s}^{-1}\right)$ than in the upper reaches of the estuary $\left(5.2 \mathrm{~J} \mathrm{~m}^{-3} \mathrm{~s}^{-1}\right)$. However, this was not strong enough to generate halocline erosion in the transitional neap to spring tidal cycle, and the estuary classification remained Type $1 b$. The main conclusions are summarized as follows: i) Two stations sampled along the Peruípe river estuary gave reasonable insight into its main thermohaline, circulation and salt transport characteristics; ii) The well-known changes in classification along an estuarine channel were confirmed for the Peruípe estuary; iii) During the fortnightly tidal modulation (neap to the spring tidal cycle) an increase in the salt transport down the estuary was observed; iv) Data fitting showed that the best results of the analytical model were obtained using the time-depth mean velocity, instead of the estimated velocity generated by the fresh water discharge.

Keywords: Thermohaline properties; circulation; observational and theoretical profiles; salt transport, periodic stratification and potential energy.

\section{Introduction}

The Caravelas-Peruípe Rivers Estuarine System (CPRES) is a shallow tropical coastal plain environment located in the southeast Brazilian coast (Bahia State). It is formed by an inner complex channel around the Cassumba Island and consists of two estuaries, the Caravelas River in the north, and the Peruípe River in the south, bordering the cities of Caravelas and Nova Viçosa, respectively. The Peruípe estuary (Fig. 1) is linked to the Caravelas estuary by a complex shallow channel and has two small tributaries, the Barra Velha and Pituaçu rivers. This estuarine system is of significant economic, social and environmental importance because it is close to the Abrolhos National Marine Park (ANMP), which encompasses the largest coral reef habitat in South Atlantic Ocean.

\section{Preferred position for figure 1}

Oceanographic data of the Caravelas estuary, mainly at its mouth and the inner shelf region have been obtained by environmental consulting companies, but their results are rarely published in scientific journals. The estuary has been seasonally sampled and a year-long time series of current and tides have been analyzed by Lessa and Cirano (2005). Tide, current and wave measurements were collected at two mooring sites located at water depths of 8 and $10 \mathrm{~m}$ at the inner shelf, and a three year time series of those data was analyzed by Teixeira (2006). 
The Bahia coastal plain experiences its highest precipitation in the austral summer (December to March), and the dry season occurs in the austral winter (June until September); the mean annual climatological height is 1,600 mm year ${ }^{-1}$ (Souza et al., 2012; Andutta et al., 2011; Izumi, 2011; Barroso, 2009). The CPRES is forced by fresh water discharge from two main rivers: the Cupído/Caravelas in the north at Caravelas $\left(17^{\circ} 45^{\prime} \mathrm{S}\right)$, empting into the ocean through two inlets (the Barra Velha and the Boca do Tomba), and the Peruípe river in the south at Nova Viçosa (lat. $17^{\circ}$ 54'S). The source of fresh water input into the Caravelas river is surface runoff into several tributaries, the Cupído river being the main one. These tributaries are distributed in a relatively small drainage basin of nearly $600 \mathrm{~km}^{2}$, but there are no data on its fresh water discharge. In the south, the main discharge comes from the Peruípe River, with climatological mean fresh water discharge of $22.5 \mathrm{~m}^{3} \mathrm{~s}^{-1} 2$ from August to September and $36.9 \mathrm{~m}^{3} \mathrm{~s}^{-1}$ from December to February (Pereira et al., 2010), according to the normalized data set of 31 years (1975 to 2006) provided by the Agência Nacional de Águas (ANA).

The most important semi-diurnal tidal components of the CPRES and their respective amplitudes (in $\mathrm{cm}$ ) are $\left(\mathrm{M}_{2} \sim 75, \mathrm{~S}_{2} \sim 34, \mathrm{~L}_{2} \sim 15, \mathrm{~N}_{2} \sim 14\right.$, and $\left.\mathrm{K}_{2} \sim 9\right)$, and the diurnal tidal components are $\left(\mathrm{O}_{1} \sim 9, \mathrm{~K}_{1} \sim 6, \mathrm{P}_{1} \sim 2, \mathrm{Q}_{1} \sim 2\right)$. The tidal co-oscillations at the estuary mouths (Caravelas and Nova Viçosa) are classified as meso-tidal and semi-diurnal $\left[\mathrm{N}_{\mathrm{f}}=\left(\mathrm{K}_{1}+\mathrm{O}_{1}\right) /\left(\mathrm{M}_{2}+\mathrm{S}_{2}\right)=0.12\right]$, respectively, according to their height and period (Lessa and Cirano, 2005; Teixeira, 2006; Andutta, 2011).

Offshore of the CPRES the continental shelf has a complex bathymetry. The coastal circulation is dominated by the Tropical Water (TW) (temperature $>20{ }^{\circ} \mathrm{C}$; salinity $>36 \mathrm{psu}$ ), according to the pioneering studies of Summerhayes et al. (1976) and Miranda and Castro (1982), which were conducted during the season of low fresh water input into the continental shelf.

The forcing of the Banco dos Abrolhos ecosystem comprises the Brazil Current (BC); its oscillations (meanders and vortices), tides and wind driven currents have influences on the physical, chemical and biological properties of the coastal and estuarine waters (Castro and Miranda, 1998). The energy and mass exchange between the estuaries of the east coast of Bahia and the narrow continental shelf may be related to the mass transport of the TW. This premise may be justified by the oligotrophic characteristic of the TW, and due to the high stability of the upper layers of the euphotic zone, it result in high concentrations in chlorophyll-a (Gaeta et al., 1999). Below the TW the BC also carries the South Atlantic Central Water (SACW), usually with high nutrient concentrations. Although it is not well known, there is evidence that the upwelled SACW in the Cabo Frio region may be advected by coastal currents to the Banco dos Abrolhos (Miranda and Castro, op. cit.; Castro et al., 2006, Pereira et al., 2005), an indication that oceanic, coastal and estuarine systems are deeply interconnected. 
Andutta (2011) presented results obtained at sampling sites $C$ and $E$ during the summer and winter seasons. The temperature along the Peruípe River Estuary is nearly homogeneous with $27.5^{\circ} \mathrm{C}$ in summer and $25^{\circ} \mathrm{C}$ in winter, and thus density stratification is driven by salinity gradients. Along the Peruípe River, the vertical stratification of salinity was almost negligible in spring tidal conditions during both summer and winter, with a maximum change through the water column of 2 psu from the bottom to the surface. In contrast, during neap tides the stratification increases and the salinity from the bottom to the surface can vary up to $\sim 10 \mathrm{psu}$ and $\sim 20 \mathrm{psu}$ at sites $\mathrm{C}$ and E, respectively. The salinity near the mouth varies between $\sim 29$ and $\sim 36 \mathrm{psu}$ in spring tides, and between $\sim 20$ and $\sim 36$ psu in neap tides.

Despite some basic knowledge on the hydrodynamics of the continental shelf, there is little scientific knowledge available on the circulation, suspended particulate matter concentration and water mass characteristics in the estuary. The main objectives of this study are to characterize the southern region of the Caravelas estuarine system, expanding on the results of Schettini and Miranda (2010) and Pereira et al. (2010), regarding its ecological importance to the Abrolhos National Marine Park, and to report on the main thermohaline and hydrodynamics characteristics of the Peruípe river estuary at Nova Viçosa (BA).

\section{Field Measurements and Methods}

The main focus of this paper is a partial analysis of the experimental data collected during the field work in the Caravelas-Peruípe Rivers Estuarine System (CPRES) for the major ProAbrolhos Project - Productivity, Sustainability and Utilization of the Abrolhos Bank Ecosystem.

Measurements of currents and hydrographic properties at a sampling rate of 30 minute intervals were acquired during 13-hour tidal cycle surveys during neap and spring tidal cycles at two

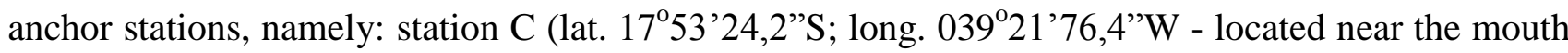
of the Peruípe River Estuary), from August 23-29, 2007 and January 16-23, 2008, and station E (lat. $17^{\circ} 53^{\prime} 12,0^{\prime \prime}$; l long. $039^{\circ} 22^{\prime} 22,0^{\prime \prime}$ W) from January 17-24, 2008 in the inner region of the estuary, about $4 \mathrm{~km}$ up estuary from station $\mathrm{C}$ (Fig. 1). The equipment used was a CTD/Current meter Valeport, model MkIII, enabling simultaneous thermohaline and current measurements. Laboratory calibration showed high precision [pressure ( $\mathrm{p} \pm 0.1$ decibar), temperature $\left(\mathrm{T} \pm 0.02^{\circ} \mathrm{C}\right)$, salinity ( $\mathrm{S} \pm 0.02 \mathrm{psu}$ - in reporting the salinity values the $\mathrm{psu}\left(\mathrm{g} \mathrm{kg}^{-1}\right)$ unity will be omitted), current intensity $\left( \pm 0.02 \mathrm{~m} \mathrm{~s}^{-1}\right)$ and direction $( \pm 1.0$ degrees $\left.)\right]$. 
The density $(\rho)$ and sigma-t $\left(\sigma_{t}\right)$ parameters were calculated with the International Equation of State of Sea Water. The velocity vector was decomposed in axial (u-component) and transverse (v-component) components according to the local referential system Oxyz, with the origin on the free surface. Ox and Oy are the longitudinal and transversal axes, oriented positively down estuary and to the left, respectively, and the vertical axis, $\mathrm{Oz}$, is oriented against the gravity acceleration.

All raw data were quality controlled, smoothed and then interpolated in terms of the nondimensional depth $(\mathrm{Z}=\mathrm{z} / \mathrm{h}(\mathrm{t}) \mid)$ at intervals, $\Delta \mathrm{Z}=-0.1$, from the surface $(\mathrm{Z}=0)$ down to the bottom $(\mathrm{Z}=-$ 1.0). It should be noted that in the velocity data processing it was assumed that $u(-1, t)=0$ as a bottom boundary condition. However, during two hours measurements were not obtained at station C (dry season) and in the spring tide there was a gap of three CTD/Current-meter profiles $(\sim 1.5 \mathrm{~h})$ due to unexpected high speeds. For the spring tide it was possible to make reasonable interpolations of the missed data. Eulerian variations of the salinity and the u-velocity component were analyzed using their tidal, non-tidal and residual values. Non-tidal (time-mean values or near steady-state profiles) were used to validate the corresponding theoretical steady-state profiles. Residual or time-depth mean values $\left(S_{a}\right.$ and $\left.u_{a}\right)$ were calculated according to Bérgamo et al. (2002).

Due to the typically small temperature variations, the thermohaline characteristics and variability of the neap-spring tidal cycles were investigated using the classical scatter T-S Diagram or State Diagram at zero hydrostatic pressure.

The description of the steady-state dynamic response and salt stratification due to the combination of the river discharge, density-driven forcing, frictional dissipative forces and wind stress forcing was approximated by the two-dimensional Hansen and Rattray (1965) analytical solution, using no-slip bottom boundary condition $[\mathrm{u}=\mathrm{u}(-1)=0]$. The Hansen and Rattray's classical model considers the balance of the barotropic and baroclinic modes, with wind stress forcing on the surface as upper boundary conditions. The central regime solutions, satisfying boundary conditions and assuming constant kinematic eddy viscosity and diffusion coefficients, for the steady-state uvelocity $\left[\mathrm{u}_{\mathrm{c}}=\mathrm{u}_{\mathrm{c}}(\mathrm{x}, \mathrm{Z})\right]$ and salinity $\left[\mathrm{S}_{\mathrm{c}}=\mathrm{S}_{\mathrm{c}}(\mathrm{x}, \mathrm{Z})\right]$ profiles in the non-dimensional depth $(-1 \leq \mathrm{Z} \leq 0)$, were obtained from the integration of the current function of the original paper (Geyer, 1997; Miranda et al. (2011).

In order to quantify the agreement between the theoretical results of the velocity and salinity profiles and the in situ data, the method suggested by (Wilmott, 1981) based in the Skill parameter, and further applied by (Warner et al., 2005; Andutta, 2006 and Andutta et al., 2006), was used, 


$$
\text { Skill }=1-\frac{\Sigma\left|X_{\text {model }}-X_{o b s}\right|^{2}}{\Sigma\left(\left|X_{\bmod e l}-\bar{X}_{o b s}\right|+\left|X_{o b s}-\bar{X}_{o b s}\right|\right)^{2}} .
$$

The quantities $\mathrm{X}_{\mathrm{obs}}$ and $\mathrm{X}_{\text {model }}$ are the observational properties ( $\mathrm{u}$-velocity component or salinity), and the corresponding values calculated by the model $\left(\mathrm{u}_{\mathrm{c}}\right.$ and $\mathrm{S}_{\mathrm{c}}$ ) and $\bar{X}_{o b s}$ its depth mean observational values. According to the equation (3), the Skill parameter varies from 1 to zero, with 1 indicating the best fit, and zero a complete disagreement between observation and the theoretical results. This validation parameter has is statistically useful when applied to time-series data, and was adapted for vertical nearly steady-state salinity and velocity profiles.

The classical Stratification-circulation diagram theoretically derived by (Hansen and Rattray, 1966) was used for the estuary classification and to calculate the relative contribution of the advective and diffusion processes to the salt transport up the estuary through its key parameter $(v)$. The nearly-steady state salinity $[S=S(x, Z)]$ and the longitudinal velocity component $[u=u(x, Z)]$ profiles were used to calculate the stratification and circulation parameters based on the half hour time-mean values of vertical profiles based on the algorithms of Miranda et al. (2002) and Bérgamo et al. (2002).

The advective salt transport components, mainly due to river discharge, tidal diffusion, Stokes drift, and density currents, were calculated according to the methodology adapted from Dyer (1974), Hunkins (1981) by Miranda et al. (1998), under the assumption that the channel was laterally homogeneous.

The main forcing mechanisms for the circulation and mixing processes and the stability characteristics of the estuary during the tidal cycle were analyzed by the classical Richardson estuarine and layer numbers $\mathrm{Ri}_{\mathrm{E}}$ and $\mathrm{Ri}_{\mathrm{L}}$, respectively (Fischer, 1976; Bowden, 1963, 1978):

$$
R i_{E}=\frac{g \Delta \rho_{H} \bar{h} \mathrm{u}_{a}}{\bar{\rho}\left(\mathrm{u}_{r m q}\right)^{3}}, \quad(2 \mathrm{a}) \text { and } \quad \operatorname{Ri}_{\mathrm{L}}(\mathrm{t})=\frac{\operatorname{gh}(\mathrm{t}) \Delta \rho_{\mathrm{V}}(\mathrm{t})}{\bar{\rho}(\mathrm{t})(\overline{\mathrm{u}})^{2}(\mathrm{t})}
$$

In the $\mathrm{Ri}_{\mathrm{E}}$ definition (eq. $\left.2 \mathrm{a}\right) \mathrm{g}, \Delta \rho_{\mathrm{H}}, \bar{h}, \mathrm{u}_{\mathrm{a}}, \bar{\rho}$ and $\mathrm{u}_{\mathrm{rms}}$ are gravity acceleration, the differences in the densities at the mouth and the estuary head, the mean depth, the residual velocity and the root mean square of the u-velocity component which controls the intensity of tidal stirring, respectively. In equation (2b) the quantities $\mathrm{h}(\mathrm{t}), \Delta \rho_{\mathrm{V}}(\mathrm{t}), \bar{\rho}(t)$ and $\overline{\mathrm{u}}(t)$ are the local depth, the bottom minus the surface densities, the mean-depth density and the mean-depth velocity, respectively. 
The physical interpretation of the layer Richardson number, according to Dyer and New (1986), is: for $\mathrm{Ri}_{\mathrm{L}}>20$ the water column is highly stable with low vertical mixing; when $\mathrm{Ri}_{\mathrm{L}}<20$ the bottom turbulence becomes effective in causing a vertical mixing process in the water column; however, below the critical value $\mathrm{Ri}_{\mathrm{L}} \sim 2$ the turbulent mixing makes the water column unstable.

The energy of the tidal Straining Process due to the Periodic Stratification (SIPS) (in this case, due to the fortnightly tidal modulation) and its influence on water column stability was calculated in terms of the potential energy anomaly $\phi$, defined by Nunes et al. (1989):

$$
\phi=\frac{1}{h} \int_{-h}^{0}(\bar{\rho}-\rho) g z d z ; \bar{\rho}=\frac{1}{h} \int_{-h}^{0} \rho(z) d z,
$$

where $\rho=\rho(\mathrm{z})$ and $\bar{\rho}$ are the density profile and its mean-depth, respectively.

The potential energy anomaly $\phi$ is the work per volume unit required to mix the water column (J $\mathrm{m}^{-3}$, in the SI system); $\phi=0$ for a well-mixed system, and increases for a highly stratified estuary. Taking into account that for a non-compressible horizontal flow the local density variation is related to the advection term by $\left(\frac{\partial \rho}{\partial t}=-u \frac{\partial \rho}{\partial y}\right)$, it is readily shown that the time rate of $\phi$ can be re-written as (Simpson et al., 1990):

$$
\frac{\partial \phi}{\partial \mathrm{t}}=\frac{\mathrm{g}}{\mathrm{h}} \frac{\partial \rho}{\partial \mathrm{x}} \int_{-\mathrm{h}}^{0}(\mathrm{u}-\overline{\mathrm{u}}) \mathrm{zdz}
$$

where $\mathrm{u}=\mathrm{u}(\mathrm{z})$ and $\overline{\mathrm{u}}$ are the $\mathrm{u}$-velocity component profile and its mean depth, respectively. In terms of the non-dimensional depth $\mathrm{Z}=\frac{\mathrm{Z}}{|\mathrm{h}|}$, this equation may be written as

$$
\frac{\partial \phi}{\partial \mathrm{t}}=\mathrm{hg} \frac{\partial \rho}{\partial \mathrm{x}} \int_{-1}^{0}(\mathrm{u}-\overline{\mathrm{u}}) \mathrm{ZdZ},
$$

and $\frac{\partial \phi}{\partial t}$ is to be expected to have low and high values for a well mixed and a highly stratified estuary, respectively. The time rate of $\phi$ will be used to compare the changes in tidal stirring intensity over the fortnightly tidal modulation in the Nova Viçosa estuary, based on the observational results of $u=u(x, Z)$ 
at stations $\mathrm{C}$ and $\mathrm{E}$, of which respective mean depth and breadth across these stations are 9 and 6 meters, and 650 and 250 meters.

Understanding the development and breakdown of stratification is very important to estuarine oceanography, as stratification in the water column is crucial in controlling the intensity of vertical mixing and hence the vertical fluxes of water properties such as heat, salt, momentum, and nutrient concentrations. This process may be of critical importance to biological production, because inhibiting vertical displacement might influence the degree of light exposure experienced by marine organisms (Simpson et al., op. cit).

\section{The forcing mechanism}

3.1 The fresh water input

The daily fresh water discharge monitored at the Helvécia station (\# 55510000 at lat. $17.7925^{\circ} \mathrm{S}$; long. $039.6048^{\circ} \mathrm{W}$ ) by the Brazilian Water National Agency (Agência Nacional de Águas-ANA) indicated the following: in the winter or dry season observational period (August, 2007), small daily variations in the fresh water discharge $\left(9.5 \mathrm{~m}^{3} \mathrm{~s}^{-1}\right.$ to $\left.12.6 \mathrm{~m}^{3} \mathrm{~s}^{-1}\right)$ were observed, with an estimated monthly mean value of $11.5 \mathrm{~m}^{3} \mathrm{~s}^{-1}$. However, in the summer or wet season (January, 2008) there were greater daily variations (from $5.0 \mathrm{~m}^{3} \mathrm{~s}^{-1}$ up to $23.1 \mathrm{~m}^{3} \mathrm{~s}^{-1}$ ), and the monthly mean value of $\sim 16.4 \mathrm{~m}^{3} \mathrm{~s}^{-1}$ was higher than the dry season. This station comprises a monitored area of $2,840 \mathrm{~km}^{2}$, and these values must be extrapolated to its entire drainage basin $\left(4,600 \mathrm{~km}^{2}\right)$; if a linear extrapolation is assumed, as a first approximation, the monthly mean values must be multiplied by a factor of $\sim 1.6$, and thus the fresh water discharge is estimated to be $18.4 \mathrm{~m}^{3}$ $\mathrm{s}^{-1}$ for the dry season and $26.2 \mathrm{~m}^{3} \mathrm{~s}^{-1}$ for the wet season (Andutta, 2011). The cross-section mean velocities due to the fresh water discharge $\left(u_{f}\right)$ were obtained based on bottom topography estimated from nautical charts, taking into account the estimated areas across stations $\mathrm{C}\left(2,100 \mathrm{~m}^{2}\right)$ and $\mathrm{E}(380$ $\mathrm{m}^{2}$ ) (Table 1). This table also presents the $\mathrm{u}_{\mathrm{f}}$ values calculated by Pereira et al. (2010), which were reasonable similar except for station $\mathrm{C}$ in the wet season.

\section{Preferred position for table 1}

3.2 Tidal oscillation and regional climate 
The regional climate is Tropical Wet with defined wet and dry seasons (Andutta, 2011). The Peruípe river estuary has almost the same tidal forcing characteristics as observed at its northern inlet (Caravelas estuary), and due to its periodic oscillation and height, it is also classified as semidiurnal and mesotidal (Andutta, 2011).

\section{Experimental and theoretical results}

The main results of the hydrographic and current measurements at stations $\mathrm{C}$ and $\mathrm{E}$ were used to study the salinity and the circulation field in the Peruípe river estuary (Andutta, op. cit.), and are summarized below.

\subsection{Neap and spring tidal experiments}

The variability of the Eulerian vertical salinity profiles $[S=S(Z, t)]$ generated by the influence of tidal currents, river discharge and diffusion, in the neap and spring tidal cycle experiments, are presented by Andutta (2011). At anchor station C, high stratification was observed during the neap tide, while in the spring tide vertical mixing eroded the haloclines and the advective influence of the ebbing and flooding tidal currents was noticeable. In the neap tide, the nearly steady-state salinity profiles $\left[S=S(Z)\right.$-not shown] change from the surface to the bottom from 28.50 to $33.40\left(S_{a}=31.70\right)$, and in the spring tide change from 33.75 to $34.47\left(\mathrm{~S}_{\mathrm{a}}=34.15\right)$, reflecting the changes in the vertical salinity stratification due to the fortnightly tidal modulation. From the neap to the spring tide the stratification parameter $\mathrm{p}_{\mathrm{e}}$ changed from 0.16 to 0.016 .

The measurements at stations $\mathrm{C}$ and $\mathrm{E}$ in the wet season (January, 2008) were made almost synoptically, and the results for the neap and spring tidal cycles are presented by Andutta (2011). As would be expected, the salinity profiles at station $\mathrm{C}$ have higher values than station $\mathrm{E}$, which is located up-estuary.

The time mean salinity profiles $[S=S(Z)]$ calculated from the Eulerian ones will be presented later, associated with their theoretical simulations, but we can anticipate the following results: At station $\mathrm{C}$, the time-mean vertical profiles increase from the surface down to the bottom from 27.10 to 34.40 in neap tide and from 33.75 to 34.20 in spring tide; at station $E$ the mean values are from 17.50 to 28.00 and from 26.20 to 30.20 in neap and spring tides, respectively (Andutta, 2011). These results indicate that in the wet season station $C$ was highly stratified in the neap tide $\left(p_{e}=0.23\right)$ and had low stratification in the spring tide $\left(\mathrm{p}_{\mathrm{e}}=0.014\right)$. At station $\mathrm{E}$ the vertical salinity structure shows 
even higher vertical stratification with the parameter varying from 0.46 in the neap tide to 0.14 in the spring tide.

The thermohaline characteristics and its variability in the neap-spring tidal cycles are shown by the scatter T-S Diagram (Fig. 2). The images of the T-S plots at station C in August, 2007 (lower) was characterized by a variation of temperature and salinity $24.3^{\circ} \mathrm{C}<\mathrm{T}<25.8^{\circ} \mathrm{C}$ and $22.0<\mathrm{S}<36.7$, respectively, between neap and spring tides. The following patterns are evident in this figure: i) the highest salinity value ( 36.7) indicates the Tropical Water (TW) intrusion in the estuary marine domain in the dry season; ii) slightly lower temperatures and higher salinities in the neap and spring tidal cycles, respectively; iii) The T-S scatter for both the flood and ebb flows at neap (white dots) and spring (black dots) tidal cycles have distinctive T-S correlations.

The images of the T-S plots at stations C and E in January, 2008 indicate higher temperatures than those observed in the dry season (August), which vary from $26.8^{\circ} \mathrm{C}$ to $29.4^{\circ} \mathrm{C}$, and are associated with salinities from 18.00 to 35.50 and 30.00 to 35.50 for the neap and spring tidal cycles, respectively (Andutta, 2011). The distinctive T-S correlation for the flood and ebb flows also occurred in the spring tide experiment, with much lower salinity variation due to the strong tidal stirring.

\section{Preferred position for figure 2}

The T-S plots at station E also indicate a significant difference between the neap and spring scatter. Temperatures were almost one degree higher during the neap tidal cycle $\left(27.7^{\circ} \mathrm{C}<\mathrm{T}<\right.$ $\left.28.7^{\circ} \mathrm{C}\right)$ than in the spring tidal cycle $\left(26.8^{\circ} \mathrm{C}<\mathrm{T}<27.7^{\circ} \mathrm{C}\right)$, and the salinity variations were from 5.0 to 34.7 and 13.0 to 34.8 , respectively. This figure shows conclusively that station $\mathrm{E}$ was located in the estuary mixing zone and salinity intrusion reached further up the estuary beyond this station during this experiment.

At station $\mathrm{C}$, in neap tide during the dry season observation period, the $\mathrm{u}$-velocity component showed variations in the interval from $-0.25 \mathrm{~m} \mathrm{~s}^{-1}$ to $0.35 \mathrm{~m} \mathrm{~s}^{-1}$, for flooding $(<0)$ and ebbing currents $(>0)($ Andutta, 2011). The time-mean velocity profile in the neap tide (not shown) indicates an unidirectional up-estuary motion with a residual velocity of $-0.05 \mathrm{~m} \mathrm{~s}^{-1}$, but this result was due to instrumentation failure during sampling(as already stated, the full tidal cycle has not been sampled). For the spring tide, a strong asymmetry was observed $\left(-0.85 \mathrm{~m} \mathrm{~s}^{-1}\right.$ to $\left.1.30 \mathrm{~m} \mathrm{~s}^{-1}\right)$ and the nearly steady-state vertical profile $\mathrm{u}=\mathrm{u}(\mathrm{Z})$ will be shown later (Fig. 4) in comparison with the simulated one indicates an unidirectional ebbing residual motion $(\mathrm{u}>0)$ with an intensity of $\mathrm{u}_{\mathrm{a}}=0.11 \mathrm{~m} \mathrm{~s}^{-1}$, which agrees well with the low vertically stratified conditions that occurred in the spring tide (Andutta, 2011). The residual velocity is higher than that estimated by the fresh water discharge (Table 1). 
The time mean velocity profiles $[\mathrm{u}=\mathrm{u}(\mathrm{Z})]$ shown by Andutta (2011) will be presented later, along with its theoretical simulations (Figs 4 to 8-right), but we can predict the following results. At anchor station $\mathrm{C}$ in the spring tide during the dry season, an unidirectional motion was indicated, characterizing a well-mixed estuary with a nearly steady state velocity of $0.11 \mathrm{~m} \mathrm{~s}^{-1}$ and a circulation parameter $\left(\mathrm{p}_{\mathrm{c}}\right)$ equal to 0.75 . However, at station $\mathrm{C}$ in the neap tide the velocity mean profile exhibited a bidirectional two layer motion with a low intensity flooding current, from $\mathrm{Z}=-0.7$ down to the bottom, characterizing a partially mixed estuary with $\mathrm{p}_{\mathrm{c}}=3.0$. In the spring tide, due to the tidal stirring, this profile became unidirectional (Fig. 6-right) which is a characteristic of a well mixed estuary with a residual speed of $0.11 \mathrm{~m} \mathrm{~s}^{-1}$ and $\mathrm{p}_{\mathrm{c}}=1.6$. At station $\mathrm{E}$ the time mean velocity profiles indicated almost the same characteristics as station $\mathrm{C}$; in the neap tide there was also a bidirectional motion (Fig. 7) and an unidirectional one in the spring tide (Fig. 8) with residual speeds of $0,11 \mathrm{~m} \mathrm{~s}^{-1}$ and $0.18 \mathrm{~m} \mathrm{~s}^{-1}$, and circulation parameters of 2.4 and 1.7 , respectively.

\subsection{Main forcing mechanism and the vertical stability}

To identify the main forcing mechanism, the estuarine Richardson number $\left(\mathrm{Ri}_{\mathrm{E}}\right)$ was calculated (eq. 2a). At station $\mathrm{C}$, during the spring tide condition in the dry season, the estuary dynamics were mainly dominated by the buoyancy input from the river discharge $\left(\mathrm{R}_{\mathrm{iE}}=2.0\right)$ and the tidal stirring was the secondary forcing. For the wet season in neap tide $\mathrm{Ri}_{\mathrm{E}}=12.9$, indicating dominance by the fresh water discharge, while in the spring tide the estuary dynamics were dominated by the tidal stirring $\left(\mathrm{Ri}_{\mathrm{E}}=0.6\right)$. During these experiments the stratification-mixing process was strongly regulated by the fresh water input and the spring-neap tidal cycle modulation.

At station $\mathrm{E}$, the estuarine Richardson numbers were $\mathrm{Ri}_{\mathrm{E}}=5.7$ and $\mathrm{Ri}_{\mathrm{E}}=4.1$ for the neap and spring tidal cycles, respectively, and the estuary was mainly forced by the fresh water discharge and was almost undisturbed by the neap to spring tidal modulation.

The water column stability was investigated by the Richardson layer number, $\mathrm{Ri}_{\mathrm{L}}$ (eq. $2 \mathrm{~b}$ ). In the neap tidal cycle the water column tends to be stable $\left(\operatorname{Ri}_{\mathrm{L}}>20\right)$ for most of the tidal cycle (Fig. 3athick line).

\section{Preferred position for figure 3}

In the spring tide; however, values of $\mathrm{Ri}_{\mathrm{L}}<<2$ and $\mathrm{Ri}_{\mathrm{L}}<20$ may be seen for several hours of the tidal cycle, except from 09:00 to 12:00, indicating low vertical stability in the water column and possible occurrence of turbulent mixing across the halocline (Fig. 3a-thin line). Similar characteristics were observed at this station in the wet season (January) as can be seen in Fig. 3b. 
The temporal variation of $\mathrm{Ri}_{\mathrm{L}}$ for the wet season at station $\mathrm{E}$ is shown during the neap tide (Fig. 3c). High vertical stability $\left(\operatorname{Ri}_{L}>20\right)$ has been shown for most of this tidal cycle, with a maximum of $\mathrm{Ri}_{\mathrm{L}} \sim 10^{8}$ which is two orders of magnitude higher than the maximum at station $\mathrm{C}$ (Fig. $3 \mathrm{a}, \mathrm{b})$; however, some short periods $(\sim 2 \mathrm{~h})$ of low stability was observed $\left(2<\mathrm{Ri}_{\mathrm{L}}<20\right)$. During the spring tide (Fig. 3d) high vertical stability occurred at the beginning and the end of the tidal cycle, while between these times $\mathrm{Ri}_{\mathrm{L}}<0$, indicating instabilities in the water column.

\subsection{Advective salt transport components}

The main residual salt transport components are presented in Table 2, whose values were calculated using equations described by Miranda et al. (2011). In the wet season (January), the salt transport down estuary due to the residual velocity had a maximum of $26.9 \mathrm{~kg} \mathrm{~s}^{-1} \mathrm{~m}^{-1}$ and $36.5 \mathrm{~kg} \mathrm{~s}^{-1}$ $\mathrm{m}^{-1}$ in neap and spring tide respectively, and is associated with lower values of the Stoke's drift $(1,0$ $\mathrm{kg} \mathrm{s}^{-1} \mathrm{~m}^{-1}$ and $\left.\sim 4,0 \mathrm{~kg} \mathrm{~s}^{-1} \mathrm{~m}^{-1}\right)$. For the remaining salt transport components the diffusion and the baroclinic forcing were found to be negligible. Moreover, the total salt transport changed from 25.0 $\mathrm{kg} \mathrm{s}^{-1} \mathrm{~m}^{-1}$ to $40.0 \mathrm{~kg} \mathrm{~s}^{-1} \mathrm{~m}^{-1}$ in the neap and spring tide, respectively.

At station $\mathrm{E}$ there was also an increase in the salt transport residual velocity from $17.1 \mathrm{~kg} \mathrm{~s}$ ${ }^{1} \mathrm{~m}^{-1}$ to $39.2 \mathrm{~kg} \mathrm{~s}^{-1} \mathrm{~m}^{-1}$ from the neap to the spring tidal conditions; however, the negative value of the Stoke's drift component $\left(-11.2 \mathrm{~kg} \mathrm{~m}^{-1} \mathrm{~s}^{-1}\right)$ in the spring-tide indicates a non-progressive tidal wave propagation. For the remaining components, a decrease (in absolute values) is observed in the upestuary salt transport from $\sim-2.5 \mathrm{~kg} \mathrm{~m}^{-1} \mathrm{~s}^{-1}$ to $\sim-0.5 \mathrm{~kg} \mathrm{~m}^{-1} \mathrm{~s}^{-1}$ for both neap and spring tides. The upestuary salt transport due to the baroclinic forcing (D component) had the following decreases (in absolute values) from the neap to the spring tidal cycles: from $-2.5 \mathrm{~kg} \mathrm{~m}^{-1} \mathrm{~s}^{-1}$ to $-0.7 \mathrm{~kg} \mathrm{~m}^{-1} \mathrm{~s}^{-1}$, respectively. An unbalanced salt transport resultant ( $\Sigma$ in the table) was observed in all experiments and between stations $\mathrm{C}$ and $\mathrm{E}$.

\section{Preferred position for table 2}

\section{Steady-state analytical simulations, estuary classification, and tidal straining}

\subsection{Steady-state analytical simulations}

In the Hansen and Rattray’s analytical steady-state solutions of the u-velocity component $\left(\mathrm{u}_{\mathrm{c}}\right)$ and salinity $\left(S_{c}\right)$ profiles, in addition to the free parameters $\left(N_{z}, K_{z}, K_{h o}\right.$ and $\left.\tau_{W}\right)$ that were obtained from the adjustment between observations and theoretical results, the following physical quantities 
obtained from the experimental results were taken into account: i) the velocity driven by the river discharge was approximated by the mean depth velocity $\mathrm{u}_{\mathrm{f}} \sim \mathrm{u}_{\mathrm{a}}$; ii) the mean water depth (h); iii) the $v$ parameter, obtained from the Stratification-circulation Diagram — sub-section 5.2, and; iv) the distance of the anchor station from the mouth $(\mathrm{x})$ measured on the nautical chart. The remaining parameters, namely the mean salinity $S_{o}$ and the longitudinal density gradient $\left(\frac{\partial \rho}{\partial x} \approx \frac{\Delta \rho}{\Delta x}\right)$ were adjusted to obtain the best theoretical versus observational profile fit as indicated by the Skill parameter. Table 3 presents the numerical values used in the theoretical simulation.

\section{Preferred position for table 3}

For Station $\mathrm{C}$ in the dry season during the spring tidal cycle, the theoretical u-velocity component $\left(\mathrm{u}_{\mathrm{c}}\right)$ and salinity profiles $\left(\mathrm{S}_{\mathrm{c}}\right)$ were compared with the corresponding observational profiles in Figs $4 \mathrm{a}$ andb, respectively.

\section{Preferred position for figure 4}

For the velocity analytical solution (Fig. 4b) it was necessary to include an up-estuary wind stress of $-0.4 \mathrm{~Pa}$, corresponding to a wind speed of $\sim 15 \mathrm{~m} \mathrm{~s}^{-1}$. Although this wind stress is due to a strong wind intensity, this forcing was necessary to justify the smaller velocity at the surface in comparison with the maximum speed at $\mathrm{Z}=-0.3$, which indicates a possible south-east wind influence at the entrance of Nova Viçosa.

At Station $\mathrm{C}$ in the wet season (January) during neap tide, the observational and theoretical results are in good agreement (Figs. 5a,b). For the $\mathrm{u}$-velocity component $\mathrm{u}_{\mathrm{c}}=\mathrm{u}_{\mathrm{c}}(\mathrm{x}, \mathrm{Z})$ and salinity $\mathrm{S}_{\mathrm{c}}=\mathrm{S}_{\mathrm{c}}(\mathrm{x}, \mathrm{Z})$ profiles, the calculated Skill parameter values are shown to be over 0.9, with a wind stress forcing down-estuary with an intensity of $0.02 \mathrm{~Pa}$, corresponding to a low wind speed of $\sim 3 \mathrm{~m} \mathrm{~s}^{-1}$. A better agreement (Skill 1.0) was obtained at this station for the spring tide (Figs. 6a,b).

\section{Preferred position for figure 5 \\ Preferred position for figure 6}

For Station $\mathrm{E}$ in the wet season (January), during neap tidal conditions, the fits (Skill parameter of 0.9 and 1.0) of the theoretical $u$-velocity component $\mathrm{u}_{\mathrm{c}}=\mathrm{u}_{\mathrm{c}}(\mathrm{x}, \mathrm{Z})$ and salinity $\mathrm{S}_{\mathrm{c}}=\mathrm{S}_{\mathrm{c}}(\mathrm{x}, \mathrm{Z})$ profiles in comparison with the corresponding observational profiles are shown in Fig. 7 (a,b).

\section{Preferred position for figure 7}

For station E during spring tide, simulation showed good agreement with theoretical profiles of the $\mathrm{u}$-velocity component $\left[\mathrm{u}_{\mathrm{c}}=\mathrm{u}_{\mathrm{c}}(\mathrm{Z})\right]$ and salinity $\left[\mathrm{S}_{\mathrm{c}}=\mathrm{S}_{\mathrm{c}}(\mathrm{Z})\right]$, with the Skill parameter equal to 0.9 and 1.0, respectively (Fig. 8a,b).

\section{Preferred position for figure 8}




\subsection{Estuary classification}

The stratification $\left(\mathrm{p}_{\mathrm{e}}\right)$ and the circulation parameters $\left(\mathrm{p}_{\mathrm{c}}\right)$ were calculated using the time-mean profiles of salinity and of the u-velocity component (description of parameters in Hansen and Rattray, 1966). These parameters are shown in the composite Stratification-circulation diagram for station $\mathrm{C}$ in the spring tide of the dry season (August-2007), and for stations C and E in the neap and spring tides during the wet season (January-2008) (Fig. 9).

\section{Preferred position for figure 9}

At station C, for the spring tide observation during the dry season (August, 2007), the circulation parameter, $p_{c}=0.75$ was less than the minimum theoretical value of 1.5 (Fig. 9) and the $v$ parameter was undetermined. This low value of $\mathrm{p}_{\mathrm{c}}$ is due to the near steady-state unidirectional velocity profile showing the maximum speed under the surface (Fig. 4, right). However, as unidirectional velocity profiles are characteristic of well mixed estuaries, it may be classified as Type 1a. In the wet season (January 2008) in the neap tide, the estuary was classified as Type $2 b$ with $v=0.92$ (partially mixed and highly stratified), and in spring tide was classified as Type 1a with $v=1.00$ (well mixed) (Fig. 9). The estuary was characterized by a unidirectional time averaged velocity profile.

The up-estuary station (E) was classified as Type $2 \mathrm{~b}(\mathrm{v}=0.88)$, partially mixed and highly stratified and during the spring tide it was classified as a highly stratified Type 1b estuary. The bidirectional steady-state velocity profile in the highly stratified condition (Fig. 7b) is due to the baroclinic gradient pressure force generated by the high stratification. The unidirectional steady-state velocity profile of the well mixed condition in the spring tide is confirmed in Fig. $8 \mathrm{~b}$.

The results for the classification of the northern dual inlet of the CPRES at Caravelas, obtained by Schettini and Miranda (2010) and Pereira et al. (2010), indicates that near the mouth the Caravelas estuary was classified as Type 1a (well mixed and low stratification), and only in the Boca do Tomba did it change to Type 2 a (partially mixed and low stratification).

\subsection{Tidal Straining}

The energy of the tidal straining process due to the fortnightly tidal modulation (from the neap to the spring tide) and its influence on water column stability was calculated in terms of the time rate of the potential energy anomaly $\left(\frac{\partial \phi}{\partial t}\right)$ (eq. 5). For such calculations that were made comparatively for stations $\mathrm{C}$ and $\mathrm{E}$, where measurements were obtained at same time in the wet season (January/2008). The steady-state results of the velocity profiles $u=u(Z)$ and its depth-mean 
value $\overline{\mathrm{u}}$ were used, and the longitudinal density gradient $\left(\frac{\partial \rho}{\partial x}\right)$ was the same used in the analytical simulations (Table 3). The results indicate a decrease in the time rate of the potential energy anomaly from $9.48 \times 10^{-3} \mathrm{~J} \mathrm{~m}^{-3} \mathrm{~s}^{-1}$ to $3.39 \times 10^{-3} \mathrm{~J} \mathrm{~m}^{-3} \mathrm{~s}^{-1}$ and $11.48 \times 10^{-3} \mathrm{~J} \mathrm{~m}^{-3} \mathrm{~s}^{-1}$ to $5.85 \times 10^{-3} \mathrm{~J} \mathrm{~m}^{-3} \mathrm{~s}^{-1}$ at stations $\mathrm{C}$ and $\mathrm{E}$, respectively, during the neap to spring tidal cycle transitional period.

\section{Discussion}

The data set of observations of currents and hydrographic properties obtained in the Peruípe river estuary at Nova Viçosa (lat. $17^{\circ} 53^{\prime}$ ), was planned for neap and spring tidal cycles in the seasons which, according to climatologic data, should be dry (August 23-29, 2007) and wet (January 16-23, 2008) conditions. However, due to a delay in the beginning of the wet season, both sampling periods occurred during similar weather conditions. Although measurements were collected at only two anchor stations and restricted to one semidiurnal Eulerian time series in the neap and spring tidal cycles, the analysis and analytical simulations with a classic model was adequate for gaining an understanding of some of its kinematics and dynamic conditions.

The main observed thermohaline characteristics were: i) the Eulerian salinity profiles showed considerable differences between the neap and spring tidal cycles, and their time variations show the advective and vertical mixing influences due to the halocline intensification and erosion. Near the mouth (St C - Fig. 1) the surface and bottom salinities vary in the intervals: $24.0<\mathrm{S}<34.4$ and $32.0<\mathrm{S}<36.5$ for the neap and spring tidal conditions in the dry season, and are lower in the wet season for the neap and spring tides $(18.0<\mathrm{S}<35.5$ and $30.5<\mathrm{S}<35.7$, respectively); ii) near Nova Viçosa city (St. E - Fig. 1) the salinities were much lower, varying in the intervals $6.0<S<33.5$ and $13.0<\mathrm{S}<35.1$ for the neap and spring tidal observations in the wet season. Near the mouth, the T-S scatter diagram indicates distinct correlations between neap to spring tidal cycles and flood to ebb, with a small temperature increase in the range of $24.3^{\circ} \mathrm{C}$ to $25.8^{\circ} \mathrm{C}$ and $27.0^{\circ} \mathrm{C}$ to $29.5^{\circ} \mathrm{C}$, for the dry and wet season, respectively. The Sigma-t variations were from $12.0 \mathrm{~kg} \mathrm{~m}^{-3}$ to $21.8 \mathrm{~kg} \mathrm{~m}^{-3}$ and $9.0 \mathrm{~kg}$ $\mathrm{m}^{-3}$ to $20.0 \mathrm{~kg} \mathrm{~m}^{-3}$ for the neap and spring tidal cycles near the mouth. Sigma-t were much lower at station E, varying in the range of $2.0 \mathrm{~kg} \mathrm{~m}^{-3}$ to $18.0 \mathrm{~kg} \mathrm{~m}^{-3}$ for the neap and spring tides. The Tropical Water (TW) mass intrusion across the estuary mouth was observed to have higher intensity in the dry season during the spring tidal cycle. High salinity values near the bottom of station $\mathrm{E}$ $(\mathrm{S}>35.0)$ also indicates this water mass intrusion.

According to Andutta (2011), in the dry season the Eulerian profiles of the u-velocity component near the estuary mouth show asymmetric behavior and lower intensities $\left(-0.32 \mathrm{~m} \mathrm{~s}^{-1}\right.$ to 
$\left.0.27 \mathrm{~m} \mathrm{~s}^{-1}\right)$ in the neap tidal cycle during the flooding $(\mathrm{u}<0)$ and ebbing $(\mathrm{u}>0)$ circulation, due to the fact that this sampling was incomplete and no further analysis was made. A velocity increase occurred during the spring tidal cycle, in the range of $-0.61 \mathrm{~m} \mathrm{~s}^{-1}$ to $1.10 \mathrm{~m} \mathrm{~s}^{-1}$. In the wet season, due to the increase in river discharge, there was an increase in the current intensities asymmetry from $0.22 \mathrm{~m} \mathrm{~s}^{-1}$ to $0.80 \mathrm{~m} \mathrm{~s}^{-1}$ and $-0.80 \mathrm{~m} \mathrm{~s}^{-1}$ to $1.60 \mathrm{~m} \mathrm{~s}^{-1}$ for the neap and spring tidal observations, respectively (Andutta, 2011), and the bidirectional velocity profiles showed low baroclinic signal in the neap tidal cycle.

The Eulerian profiles of the u-velocity component at the upper reaches in the neap tidal cycle in the wet season (Andutta, 2011) have some similarities with velocity profiles at station C: low baroclinic signal and intensities varying $-0.39 \mathrm{~m} \mathrm{~s}^{-1}$ to $0.78 \mathrm{~m} \mathrm{~s}^{-1}$. However, in the spring tide observation the asymmetry increases from $-0.38 \mathrm{~m} \mathrm{~s}^{-1}$ to $0.98 \mathrm{~m} \mathrm{~s}^{-1}$ and the vertical profiles indicates a pronounced barolinic signal (Andutta, 2011).

The non-tidal velocity profiles near the mouth (St. C) indicate the following characteristics: i) unidirectional flow, which is a characteristic of a well-mixed estuary, in the spring tide of the dry season, with a nearly steady-state residual current intensity of $0.11 \mathrm{~m} \mathrm{~s}^{-1}$ (Fig. 4); ii) a two-layer estuarine circulation of the partially mixed estuaries with no-motion depths at $\mathrm{Z}-0.75$, characterized by a weak baroclinic signal in neap tide in the wet season, with a nearly steady-state residual current intensity $0.09 \mathrm{~m} \mathrm{~s}^{-1}$ (Fig. 5); and iii) unidirectional flow of well-mixed estuaries in the spring tide in the wet season, with a nearly steady-state residual current intensity $0.11 \mathrm{~m} \mathrm{~s}^{-1}$ (Fig. 6). In the upestuary region (St. E) almost the same characteristics (ii and iii) were observed as in station C, but with a stronger baroclinic signal near the bottom in the neap tide observations (Fig. 7). The nearly steady-state residual current intensities were $0.11 \mathrm{~m} \mathrm{~s}^{-1}$ and $0.18 \mathrm{~m} \mathrm{~s}^{-1}$, for the neap and spring tidal observations, respectively.

\section{Conclusions}

Near the estuary mouth (St. C) and in the spring tide of the dry season, the Peruípe estuary was as classified as Type 1a (well mixed), but its $v$ parameter was undetermined because $v$ was lower than 1 . However, in the wet season the estuary alternates from being Type $2 b$ (partially mixed and highly stratified), with $v=0.92$ in the neap tide, to being Type 1 a (well mixed with low stratification), with $v=1.00$ during the spring tide. At station $\mathrm{E}$, in the wet season the estuary was classified as Types $2 \mathrm{~b}$ (partially mixed and highly stratified) and $1 \mathrm{~b}$ (highly stratified) in the neap and spring tidal cycles, respectively, with $v$ parameter changing from 0.88 in neap tide to 0.99 in 
spring tide, which are in close agreement with Schettini and Miranda (2010) e Pereira et al. (2010). These results show that this estuarine region was less sensitive to the time scale of the tidal fortnightly modulation and support the conclusion that the tidal energy increase energy increase (decrease) of $5.2 \mathrm{~J} \mathrm{~m}^{3} \mathrm{~s}^{-1}$ was not enough to erode the halocline, even in the high stratification conditions. The up-estuary salt transport was dominated by the tidal diffusion process. These results also are in close agreement with the characteristics of the nearly steady-state velocity bidirectional (with a weak barolinic signal) and unidirectional profiles.

In the wet season, the estuary upper reaches was forced mainly by the fresh water discharge $\left(\mathrm{Ri}_{\mathrm{E}}=5.7\right.$ and $\left.\mathrm{Ri}_{\mathrm{E}}=4.1\right)$. However, the region near the estuary mouth was strongly modulated by the tide, and the main forcing mechanism changed from fresh water discharge $\left(\mathrm{Ri}_{\mathrm{E}}=12.9\right)$ to tidal stirring $\left(\mathrm{Ri}_{\mathrm{E}}=0.60\right)$ for the neap and spring tidal cycles, respectively.

The time variation of the layer Richardson number near the estuary mouth during the neap tide was much higher than the upper limit $\left(\operatorname{Ri}_{\mathrm{L}}>20\right)$, and the turbulent mixing across the halocline was suppressed. However, in the spring tidal cycle values lower than the critical number $\left(\mathrm{Ri}_{\mathrm{L}}<20\right)$ and in those cases the bottom turbulence may become effective.

In the wet season when both stations ( $\mathrm{E}$ and $\mathrm{C}$ ) were sampled almost simultaneously, a downward increase in the net salt transport down estuary was observed in both the neap (from 14.8 $\mathrm{kg} \mathrm{m}^{-1} \mathrm{~s}^{-1}$ to $25.1 \mathrm{~kg} \mathrm{~m}^{-1} \mathrm{~s}^{-1}$ ) and spring tide (from $26.8 \mathrm{~kg} \mathrm{~m}^{-1} \mathrm{~s}^{-1}$ to $39.6 \mathrm{~kg} \mathrm{~m}^{-1} \mathrm{~s}^{-1}$ ). This increase may be due to the contribution of the interconnection channel (Peruípe and Caravelas estuaries), and/or to the rivers that empty near the mouth of the Peruípe estuary, but this hypothesis should be investigated.

The steady-state of salinity and the u-velocity component profiles were simulated with the classical Hansen and Rattray (1965) analytical model. Although some adjustments had to be made in the free parameters, a good agreement (Skill $~ 1.0$ ) between the theoretical and experimental profiles was obtained. Hence, the classical momentum balance was appropriate to describe the essential steady-state dynamics of the estuarine channel, which were mainly due to the fresh water discharge, the baroclinic gradient pressure and the dissipative frictional forces. The best results of the analytical model were obtained using the time-depth mean velocity, instead of the velocity generated by the fresh water discharge, which was much lower due to its interpolation from the gauging station to the estuary head and/or the poor knowledge of the cross sectional area. The magnitudes of the free parameters $\mathrm{N}_{\mathrm{z}}, \mathrm{K}_{\mathrm{z}}$ and $\mathrm{K}_{\mathrm{ho}}$ (kinematics vertical eddy viscosity and diffusion, and horizontal diffusion) may be helpful as initial values in analytical or numerical simulations.

\section{Acknowledgements}


This paper is part of the estuarine experiment held in the Project Produtividade, Sustentabilidade e Utilização do Ecossistema do Banco de Abrolhos - PROABOLHOS - Institutos do Milênio 2005-2008, MCT/CNPq (CNPq grant 420219/2005-6 to Eurico Cabral de Oliveira), realized thanks to the cooperation of IOUSP, UNIVALI and UFRN. We wish to acknowledge the kind assistance in the field work from Piero L. F. Mazzini, Marçal D. Pereira, Cassia Pianca, and the collaboration of other graduate students and technicians of the Dept. of Physical, Chemistry and Geology of IO-USP, PPGGeo/UFRGS and UFRN for their assistance with the field work and data processing is very much appreciated. We are also grateful for the support from the Conselho Nacional de Desenvolvimento Científico e Tecnológico (CNPq) for the Ph. D. and M.Sc. students fellowships and the P\&P (Procs. LBM-302069/2004-6, CAFS-306217/2007-4 and ES-308303/20067). The main equipment used was acquired with the incentives of the Brazilian law (Lei 8010 and Portaria MCT/MF 445/98).

\section{References}

Andutta, F.P., 2011. O Sistema Estuarino dos rios Caravelas e Peruípe (Bahia): Observações, simulações, tempo de residência e processos difusivo e advectivo. $\mathrm{PhD}$ Thesis. Instituto Oceanográfico da Universidade de São Paulo. S Paulo, 142 pp.

Andutta, F. P, Miranda, L. B., Castro, B. M., Fontes, R. F. C., 2006. Numerical Simulation of the Hydrodynamic in the Curimataú Estuary, RN Brazil. Oceanography and Global Changes, SPBrazil, 545-558.

Andutta, F.P., 2006. Experimentos e modelagem numérica com aplicação ao estuário tropical do rio Curimataú, RN. MSc Thesis. Instituto Oceanográfico da Universidade de São Paulo. S Paulo, $122 \mathrm{pp}$.

Barroso, C.P., 2009. Dinâmica de bancos e pontais arenosos associados à desembocadura do estuário de Caravelas, BA. MSc Thesis. Instituto Oceanográfico da Universidade de São Paulo. S Paulo, 117 pp.

Bérgamo, A.L., Miranda, L.B., Corrêa, M.A 2002. Estuário: Programas para processamento e análise de dados hidrográficos e correntográficos. Rel. Téc. Instituto Oceanográfico, São Paulo 49, 116.

Bowden, K. F., 1963. The Mixing Processes in a Tidal Estuary. J. Air Wat. Pollut., 7, 343-356.

1978. Mixing Processes in Estuaries. In: Estuarine Transport Processes, ed. B. Kjerfve. Belle W. Baruch Library In Marine Science, No. 7, University of South Carolina Press, Columbia, S.C., 11-36.

Castro B.M., Miranda, L.B., 1998. Physical Oceanography of the Western Atlantic Continental Shelf located between $4^{\circ} \mathrm{N}$ and $34^{\circ} \mathrm{S}-$ Coastal Segment $(4, \mathrm{~W})$. In: Robinson, A.R. and Brink, K.H. (Ed). The Sea. New York. John Willey \& Sons 11, 209-251.

Castro, B.M., Vanin, A.M.S.P., Brandini, F., Miranda, L.B., 2006. Multidisciplinary oceanographic processes on the Western Atlantic continenal shelf between $4^{\circ} \mathrm{S}$ and $34^{\circ} \mathrm{S}(4, \mathrm{~W})$. In: Robinson, A.R. and Brink, K.H. (Ed). The Sea. New York. John Willey \& Sons 14, 259293.

Defant, A., 1961. Physical Oceanography. Oxford, Pergamon Press 2, 598 pp. 
Dyer, K.R.1974. The Salt Balance in Stratified Estuaries. Estuarine and Coastal Marine Science. 2, 273-281.

Dyer, K.R., A. L. New 1986. Intermittency in estuarine mixing. In: Estuarine Variability, ed. D.A. Wolfe, Academic Press, Orlando, Fla, 321-339.

Fischer, H.B.1976. Mixing and Dispersion in Estuaries. Annual Review of Fluid Mechanics. 8, 107133.

Gaeta, S.A., Lorenzzetti, J.A., Miranda, L.B., Susini-Ribeiro, S.M.M., Pomperu, M., Araujo, C.E.S., 1999. The Vitoria Eddy and its relation to the shelf phytoplankton biomass and primary productivity during the austral fall of 1995. Archive of Fishery and Marine Research. 47(2-3), 253-270.

Geyer, W.R., 1997. On the influence of wind on the dynamics and flushing in shallow estuaries. Estuar. Coast. Shelf. Sci. (44), 713-722.

Hansen, D.V., Rattray M., Jr., 1965. Gravitational Circulation in Sraits and Estuaries. Journal of Marine Research. 23(1), 102-122.

Hansen, D.V., Rattray M., Jr., 1966. New Dimensions in Estuary Classification. Liminology and Oceanography. 11(3), 319-325.

Hunkins, K., 1981. Salt Dispersion in the Hudson Estuary. Journal of Physical Oceanography. (11), 729-738.

Izumi, V.M., 2006. Comparação entre as desembocaduras do Complexo Estuarino do Cassurubá (BA): Características hidrográficas e hidrodinâmicas. MSc Thesis. Instituto Oceanográfico da Universidade de São Paulo. S Paulo, 115 pp.

Leipe, T., Knoppers, B., Marone, E., Camargo, R., 1999. Suspended matter transport in coral reef waters of shelf Abrolhos bank, Brazil. Geo-Marine Letters 19, 186-195.

Lessa, G.C., Cirano, M., 2005. On the circulation of a costal channel within the Abrolhos Coral-Reef system Southern Bahia, Brazil. Journal of Coastal Research 39(SI), 450-453.

Miranda, L.B., Castro, B.M., Kjerfve, B., 1998. Circulation and mixing in the Bertioga Channel (SP, Brazil). Estuaries 21(2), 204-214.

Miranda, L.B., Castro, B.M., 1982. Geostrophic flow conditions of the Brazil Current at $19^{\circ}$ S. Ciência Interamericana 44, 44-48.

Miranda, L.B., Castro, B.M., Kjerfve, B., 2002. Princípios de Oceanografia Física de Estuários. S. Paulo, EDUSP, 424 pp. (Acadêmica 42).

Miranda, L.B., Castro, B.M., Kjerfve, B., 2011. Princípios de Oceanografia Física de Estuários. S. Paulo, EDUSP, 432 pp. $2^{\text {nd }}$ edition (Acadêmica 42).

Miranda, L. B., Bérgamo, A. L., Castro, B. M., 2005. Interactions of river discharge and tidal modulation in a tropical estuary, NE, Brazil. Ocean Dynamics 55, 430-440.

Nunes, R.A., Lennon, G.W., Samarasinghe, J.R.S., 1989. The Negative Role of Turbulence in Estuarine Mass Transport. Estuarine, Coastal Shelf Science 28, 361-377.

Officer, C.B., 1976. Physical Oceanography of Estuaries and Associated Coastal Waters, John Wiley \& Sons. N.Y., 465 pp.

Officer, C.B., 1977. Longitudinal Circulation and Mixing Relations in Estuaries. Estuaries, Geophysics, and the Environment. Studies in Geophysics. The National Research Council, 13-21.

Pereira, M.D., Siegle, E., Miranda, L.B., Schettini, C.A.F., 2010. Hidrodinâmica e transporte de material particulado em suspensão sazonal em um estuário dominado pela maré: Estuário de Caravelas(BA). Revista Brasileira de Geofísica 28(3), 427-444.

Pereira, A.F., Belem, A.L., Castro, B.M., Geremias, R., 2005. Tide-topography interaction along the Eastern Brazilian shelf. Continent. Shelf Res. 25(12-13), 1521-1539.

Prandle, D., 1985. On Salinity Regimes and the Vertical Structure of Residual Flows in Narrow Tidal Estuaries. Estuar. Coastal Shelf Sci. (20), 615-635. 
Prandle, D., 2004. Saline intrusion in partially mixed estuaries. Estuarine, Coastal Shelf Science. (59), 385-397.

Schettini, C.A.F., Miranda, L.B., 2010. Circulation and suspended particulate matter in a tidally dominated estuary: Caravelas estuary, Bahia, Brazil. Brazilian Journal of Oceanography 58(1), 1-11.

Simpson, J.H., Brown, J., Mattews, J., Allen, G., 1990. Tidal straining, Density Currents, and Stirring in the Control of Estuarine Stratification. Estuaries 13(2), 125-132.

Sousa, S.H.M., Amaral, P.G.C., Martins, V., Figueira, R.C.L., Siegle, E., Ferreira, P.A.L., Silva, I.S., Shinagawa, E., Salaroli, A., Schettini, C.A.F., Cruz, Santa J., Mahiques, M.M., 2012. Environmental Evolution of the Caravelas Estuary (Northeastern Brazilian Coast, $17^{\circ} \mathrm{S}, 39^{\circ}$ W) Based on Multiple Proxies in a Sedimentary Record of the Last Century. Journal of Coastal Research, in press.

Summerhayes C., Melo, U.D., Barretto, H., 1976. The influence of upwelling on suspended matter and shelf sediments off southeastern Brazil. J. sedim. Petrology 46(4), 819-828.

Teixeira, C.E.P., 2006. Caracterização e variabilidade da hidrodinâmica da zona costeira adjacente ao banco de Abrolhos. MSc Thesis. Instituto Oceanográfico, USP, São Paulo, 93 pp.

Warner, J.C., Geyer, W.R., Lerczak, J.A., 2005. Numerical modeling of an estuary: A comprehensive skill assessment. Journal of Geophysical Research. 110(CO5001), 1-13.

Wilmott, C. J., 1981. On the validation models. Physical Geography (2), 184-194. 


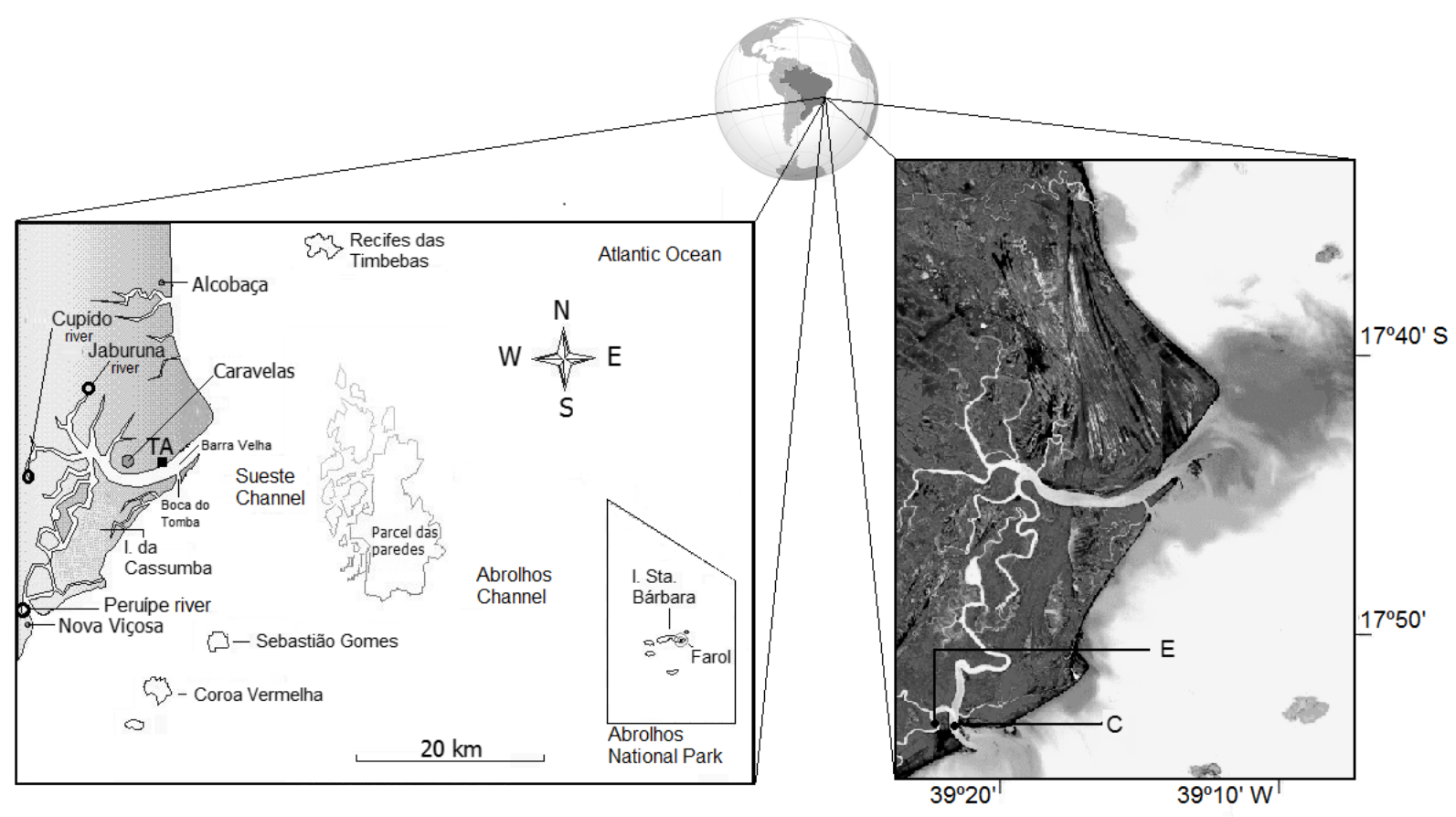

Figure 1 - The Caravelas-Peruípe Rivers Estuary System and east coastal region (left) showing some islands of the Abrolhos Archipelago and in the southeast the Abrolhos National Marine Park. The locations of the $\mathrm{C}$ and $\mathrm{E}$ anchor stations south of the estuarine system at Nova Viçosa (right). Adapted from Andutta (2011). 


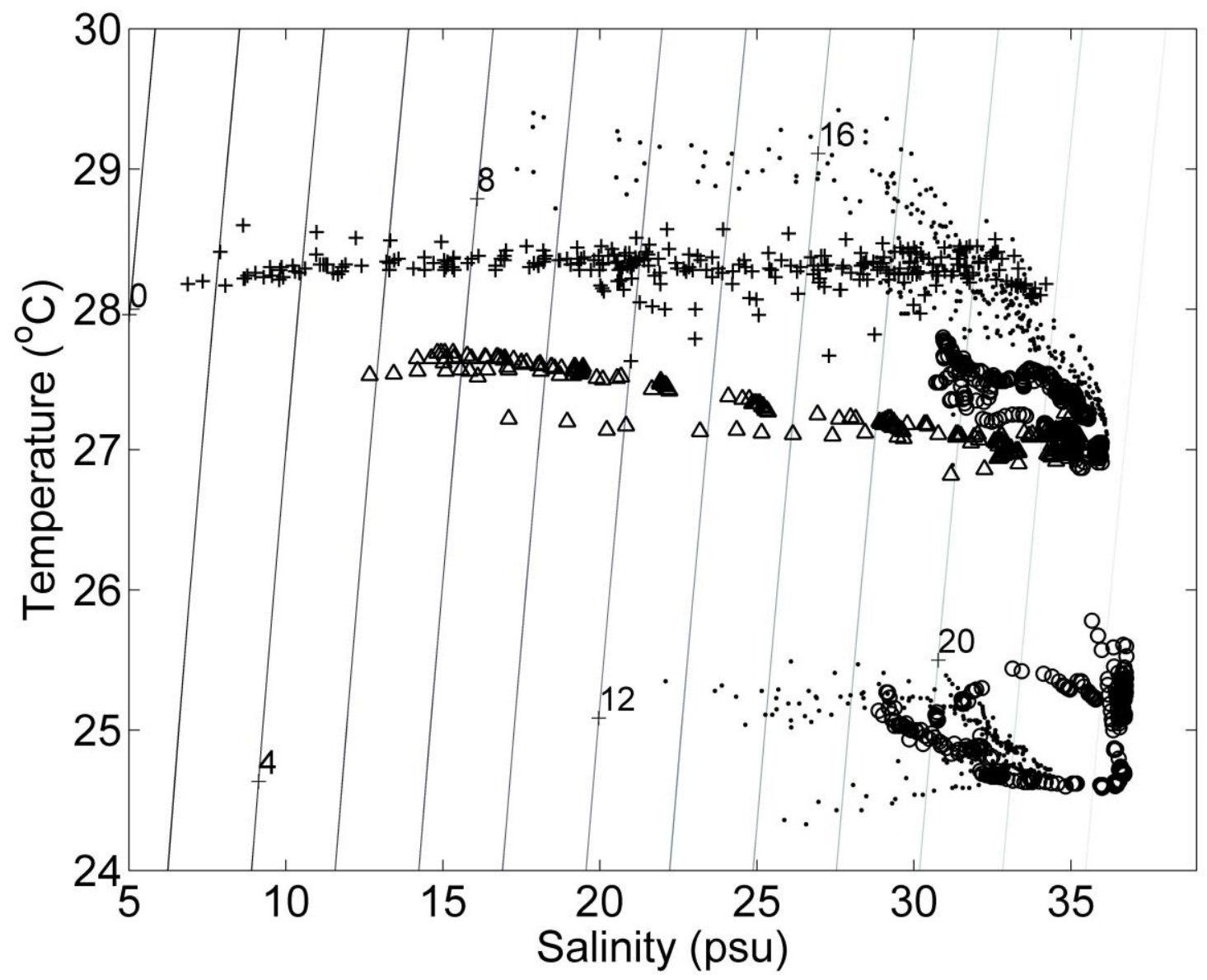

Figure 2 - T-S diagrams for the neap ( $\bullet$ ) and spring (o) tides at station C lower scatter (23 and 29 of August, 2007), and for the same tidal conditions sampled at stations C and E (16 and 24 of January, 2008 for neap and spring tide, respectively); same symbols for $\mathrm{C}$, and for E symbols + and $\Delta$ indicate neap and spring tide, respectively. 

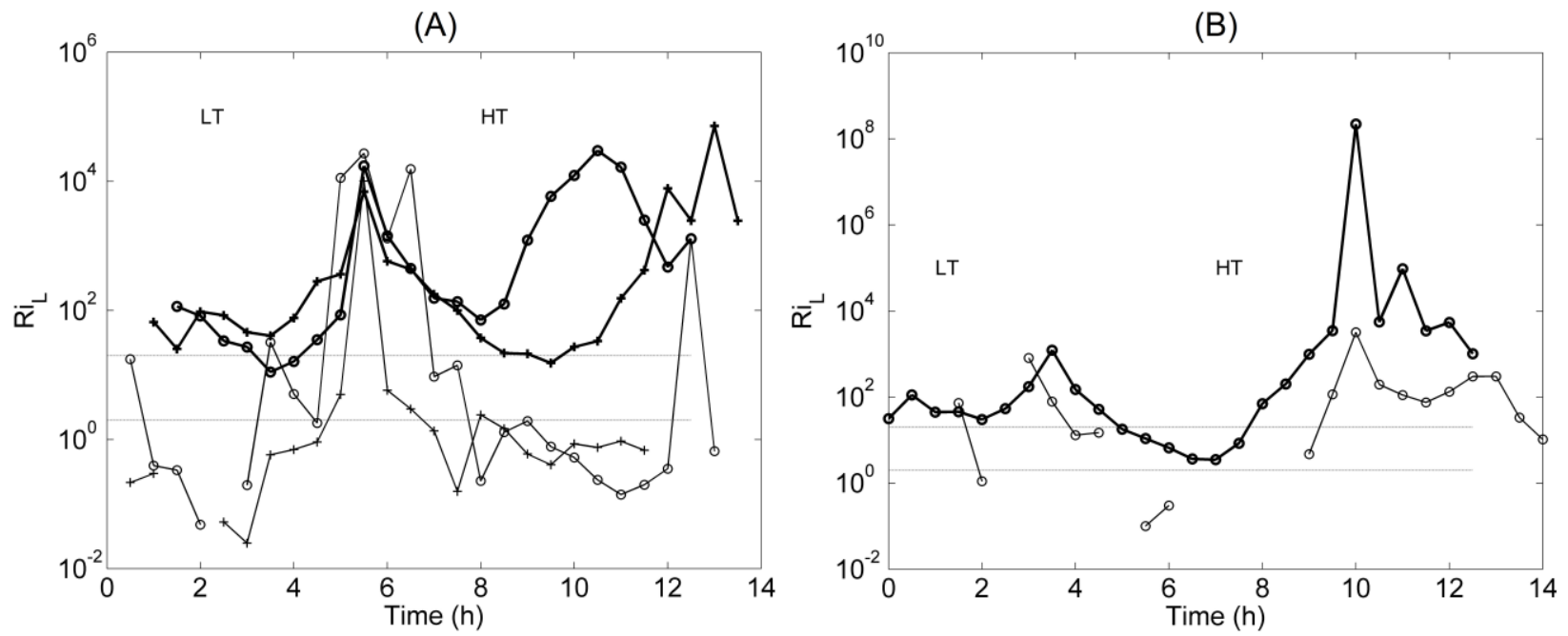

Figure 3 - (A) Time variation of the layer Richardson number $\left(\operatorname{Ri}_{\mathrm{L}}\right)$ at Station $\mathrm{C}$ during the neap (thick line) and spring (thin line) tides, obtained in both winter (August 2007, lines with circles) and summer seasons (January 2008, lines with crosses). (B) Time variation of $\left(\mathrm{Ri}_{\mathrm{L}}\right)$ at Station $\mathrm{E}$ during neap (thick line) and spring tides (thin line), obtained in the summer (January 2008). LT and HT indicates high and low tide. 
(A)

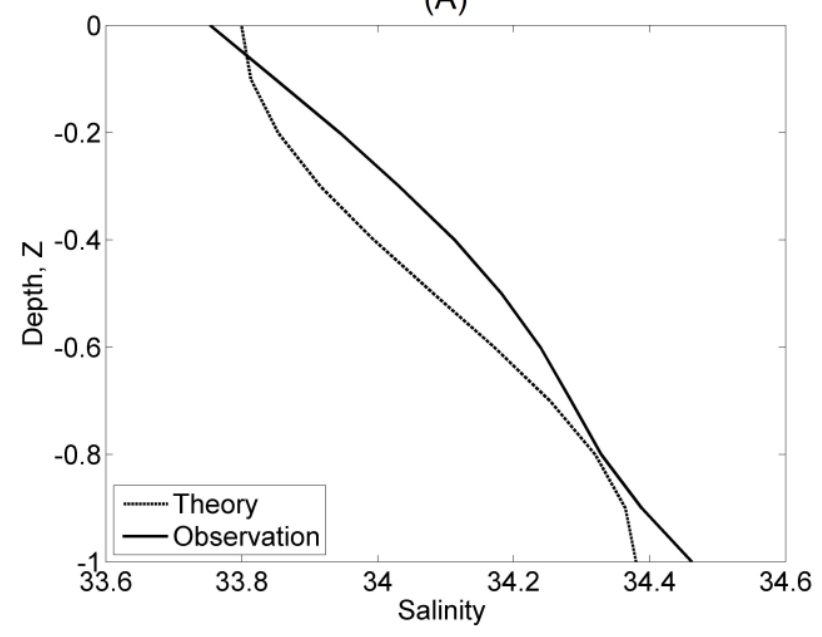

(B)

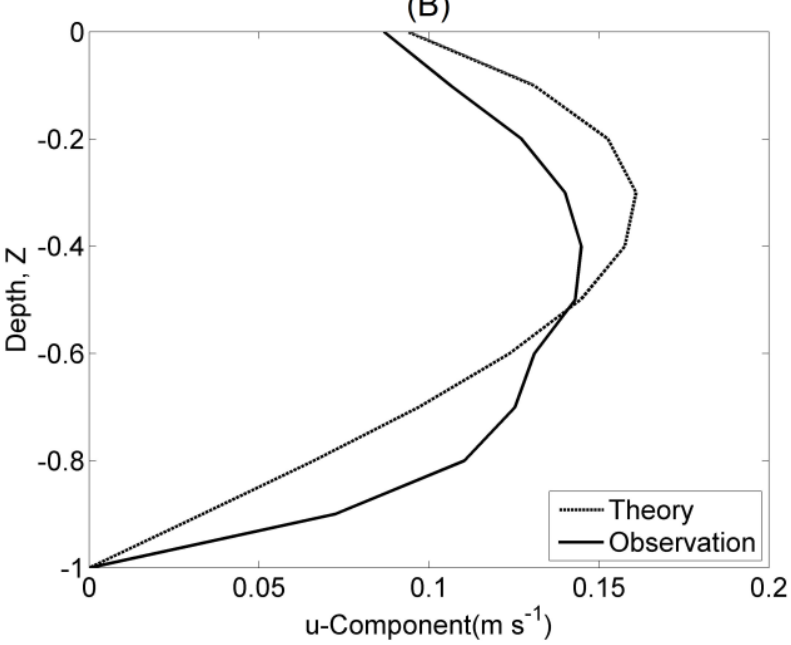

Figure 4 - Salinity (A) and u-velocity component (B) observational and theoretical profiles at the Station $C$ in the spring tidal cycle of the dry season (August 29, 2007), validated with the Skill parameter with calculated value of 0.9 for (A) and (B). Nearly steady-state salinity and velocity observational values were 34.1 and $0.11 \mathrm{~m} . \mathrm{s}^{-1}$. 
(A)

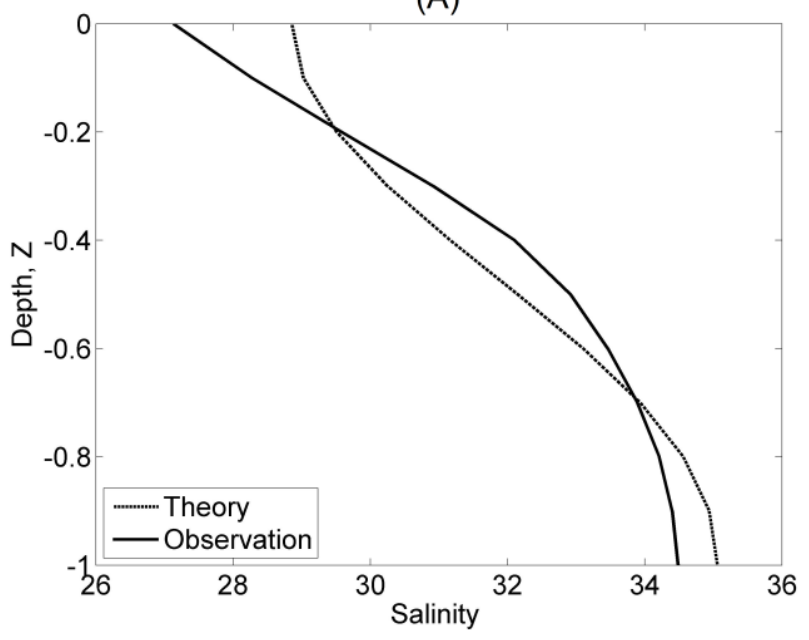

(B)

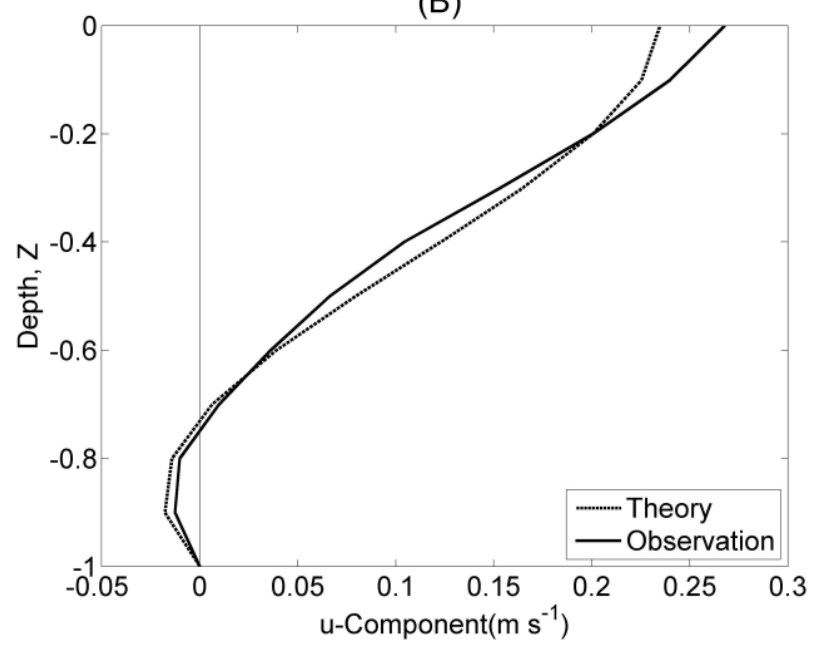

Figure 5 - Salinity (A) and u-velocity component (B) observational and theoretical profiles of at the Station $C$ in the neap tidal cycle of the wet season (January 16, 2008), validated with the Skill parameter with calculated value of 0.9 and 1.0 for (A) and (B), respectively. Nearly steady-state salinity and velocity observational values were 32.1 and $0.09 \mathrm{~m} . \mathrm{s}^{-1}$. 
(A)

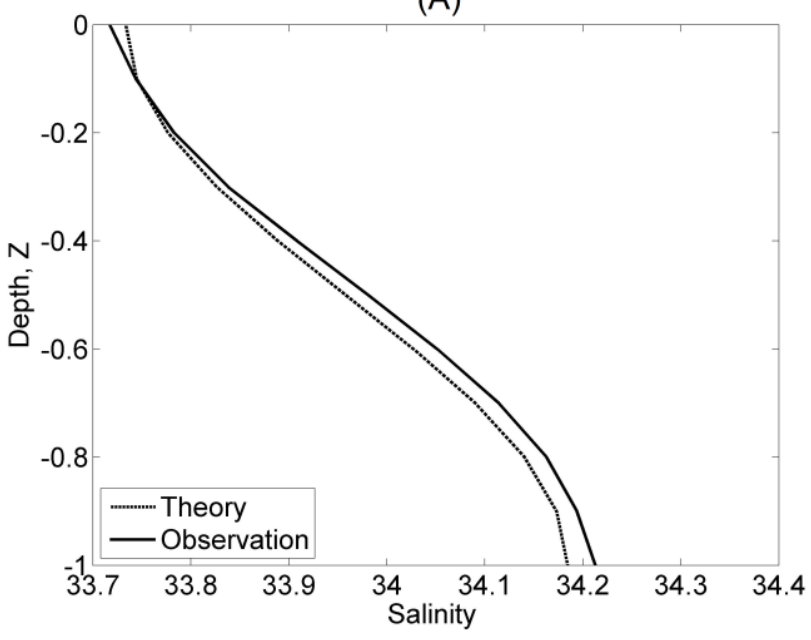

(B)

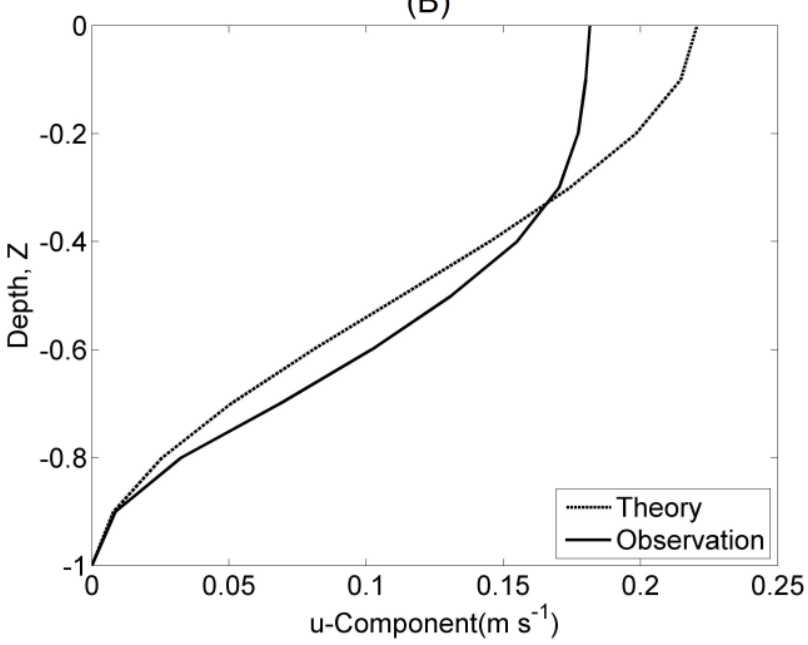

Figure 6 -Salinity (A) and u-velocity component (B) observational and theoretical profiles at the Station $\mathrm{C}$ in the spring cycle of the wet season (January 23, 2008), validated with the Skill parameter with calculated value of 1.0 for (A) and (B). Nearly steady-state salinity and velocity observational values were 34.0 and $0.11 \mathrm{~m} . \mathrm{s}^{-1}$. 
(A)

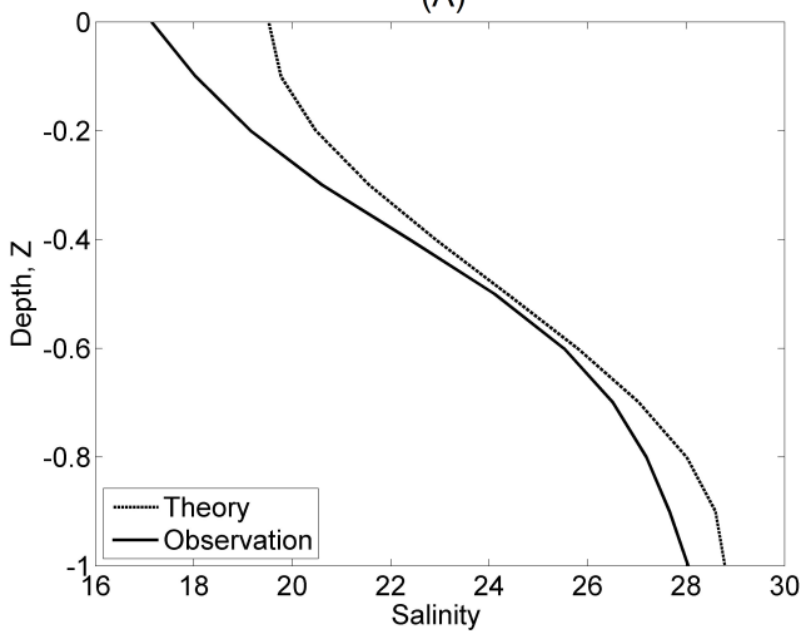

(B)

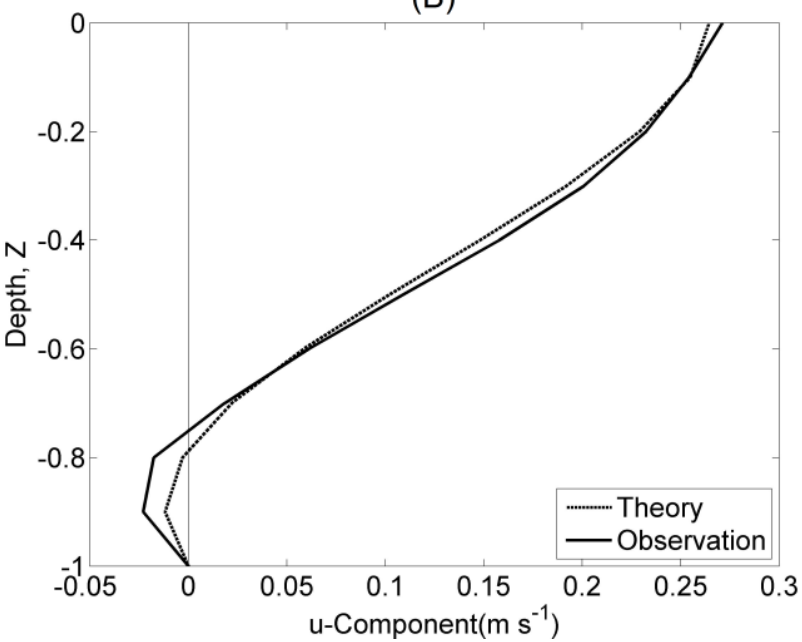

Figure 7 - Observational versus theoretical profiles of salinity (A) and u-velocity component (B) at the Station E in the neap tidal cycle of the wet season (January 17, 2008). Skill is the validation parameter with calculated value of 0.9 and 1.0 for (A) and (B), respectively. Nearly stationary salinity and velocity observational values were 23.4 and $0.11 \mathrm{~m} . \mathrm{s}^{-1}$. 
(A)

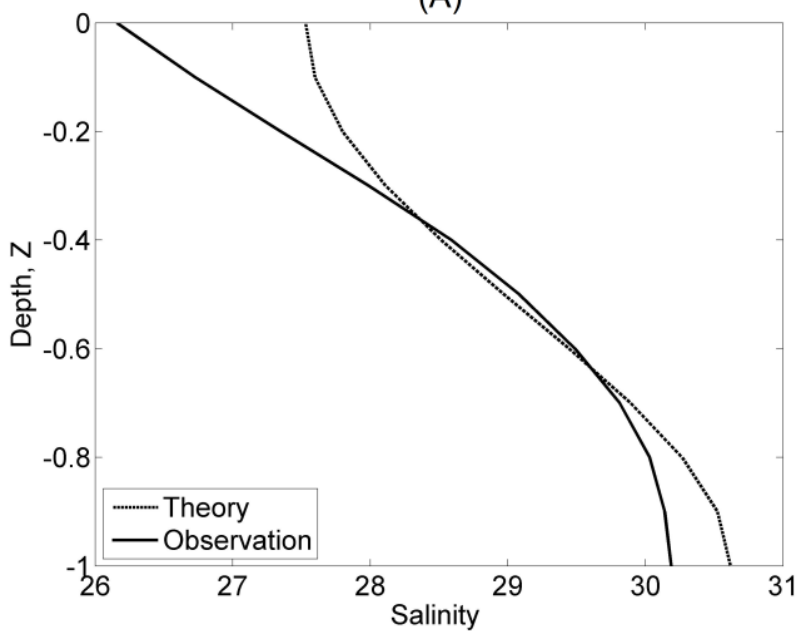

(B)

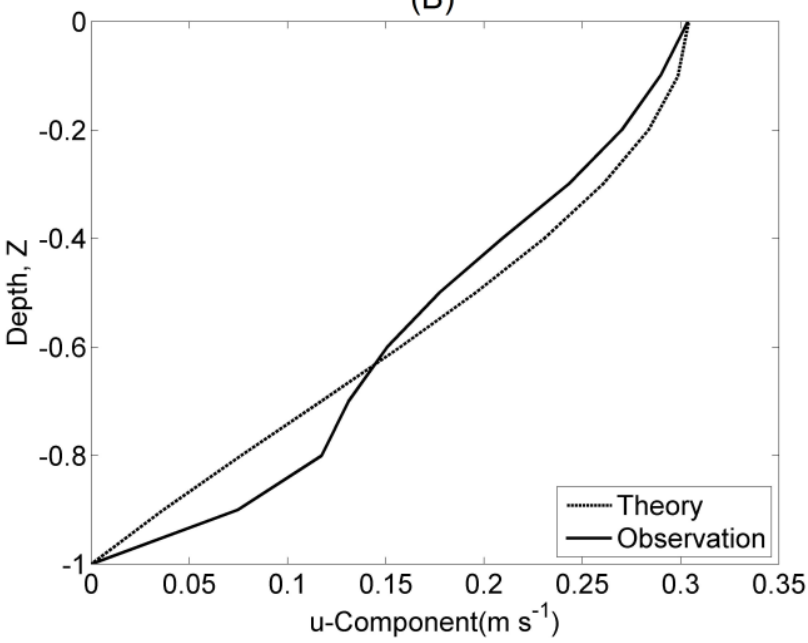

Figure 8 - Salinity (A) and u-velocity component (B) observational and theoretical profiles at the Station E in the spring tidal cycle of the wet season (January 24, 2008), validated with the Skill parameter with calculated value of 0.9 and 1.0 for (A) and (B), respectively. Nearly steady-state salinity and velocity observational values were 28.7 and $0.18 \mathrm{~m} . \mathrm{s}^{-1}$. 


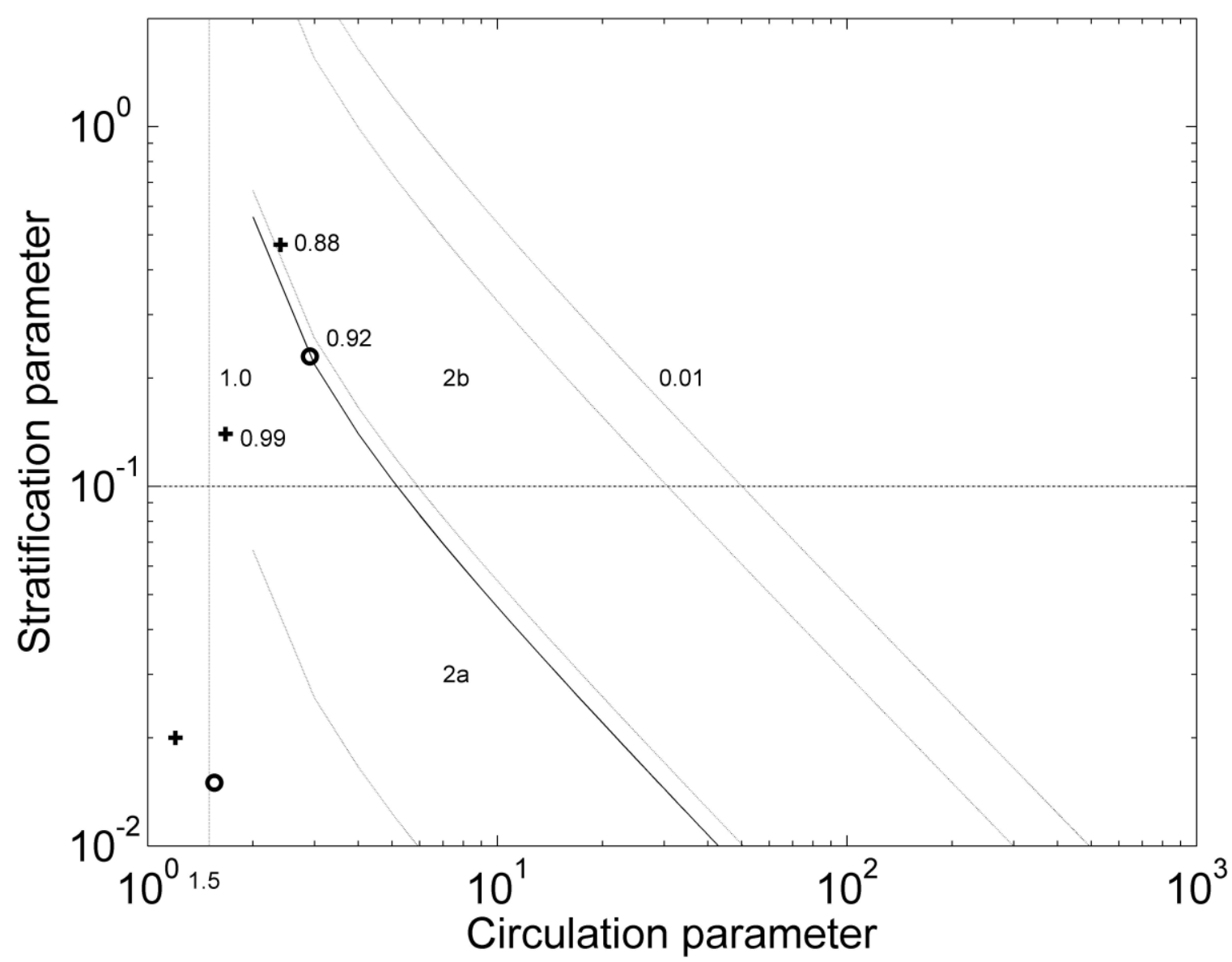

Figure 9 - Stratification-circulation diagram and classification changes observed in stations C (cross) and $\mathrm{E}$ (circle) due to the fortnightly tidal modulation in January, 2008 (wet station). Station C classified as Type $1 \mathrm{a}$ with $v=1.00$ and Type $2 \mathrm{~b}$ with $\mathrm{v}=0.92$ at spring and neap tide, respectively. Station $E$ as Types $2 b$, with $v=0.99$ and $v=0.88$. Black square $\left(p_{c}<1.5\right)$ is the result for the station $C$ in the spring of August, 2007 (dry season). 
Table 1 - Estimated values of the velocity $\left(\mathrm{m} . \mathrm{s}^{-1}\right)$ generated by the fresh water discharge in the stations C and E cross sections for the dry (August/2007) and wet (January/2008) months. Source: Hidroweb - ANA. In parenthesis the values calculated by Pereira et al. (2010).

\begin{tabular}{ccc}
\hline Site & August/2007 & January/2008 \\
\hline E & $0.05(0.08)$ & $0.07(0.07)$ \\
$\mathrm{C}$ & $0.01(0.01)$ & $0.01(0.07)$ \\
\hline
\end{tabular}


Table 2 - Main advective salinity transport components for the spring tidal cycle (Sp) experiments in stations C (January 16-23, 2008) and E (January 17-24, 2008). A-Residual velocity (river input); BStokes drift; C-Tidal diffusion and D-Baroclinic forcing, in $\left(\mathrm{kg} \mathrm{m}^{-1} \cdot \mathrm{s}^{-1}\right)$.

\begin{tabular}{ccccc}
\hline & $\begin{array}{c}\text { St C } \\
\text { January/Np }\end{array}$ & $\begin{array}{c}\text { St C } \\
\text { January/Sp }\end{array}$ & $\begin{array}{c}\text { St E } \\
\text { January/Np }\end{array}$ & $\begin{array}{c}\text { St E } \\
\text { January/Sp }\end{array}$ \\
\hline A & 26.9 & 36.5 & 17.1 & 39.2 \\
B & 0.8 & 3.9 & 2.8 & -11.2 \\
C & -0.6 & -0.7 & -2.6 & -0.5 \\
D & -2.0 & -0.1 & -2.5 & -0.7 \\
$\Sigma$ & 25.1 & 39.6 & 14.8 & 26.8 \\
\hline
\end{tabular}


Table 3 - Free parameters and those estimated from the measurements $(*)$. These parameters were used to simulate the steady-state profiles of the $\mathrm{u}$-velocity component $\left(\mathrm{u}_{\mathrm{c}}\right)$ and salinity $\left(\mathrm{S}_{\mathrm{c}}\right)$. Data from the spring tidal cycle experiment (August 29, 2007) and the neap-spring tidal cycles at the stations C (January 16-23, 2008) and E (January 17-24, 2008). Physical properties in SI units, and $S_{p}$ and $N_{p}$ indicate spring and neap tidal observations, respectively.

\begin{tabular}{cccccc}
\hline & St C August/Sp & St C & St C & St E & St E \\
& & January/Np & January/Sp & January/Np & January/Sp \\
\hline$* \mathrm{u}_{\mathrm{f} \approx} \mathrm{u}_{\mathrm{a}}$ & 0.11 & 0.09 & 0.11 & 0.11 & 0.18 \\
$* \mathrm{~h}$ & 7.0 & 9.0 & 9.5 & 6.5 & 7.5 \\
$* \mathrm{v}$ & 1.0 & 0.92 & 1.00 & 0.88 & 0.99 \\
$* \mathrm{~S}_{\mathrm{o}}$ & 34.0 & 31.0 & 33.65 & 23.5 & 28.7 \\
$* \mathrm{~S}_{\mathrm{mouth}}$ & 37.0 & 37.0 & 37.0 & 37.0 & 37.0 \\
$* \mathrm{~S}_{\text {head }}$ & 1.0 & 1.0 & 1.0 & 1.0 & 1.0 \\
$* \Delta \mathrm{x}$ & $8.0 \times 10^{3}$ & $9.5 \times 10^{3}$ & $1.0 \times 10^{4}$ & $3.5 \times 10^{3}$ & $8.0 \times 10^{3}$ \\
$* \mathrm{x}$ & $1.8 \times 10^{3}$ & $1.8 \times 10^{3}$ & $1.8 \times 10^{3}$ & $4.0 \times 10^{3}$ & $4.0 \times 10^{3}$ \\
$\mathrm{~N}_{\mathrm{z}}$ & $6.0 \times 10^{-3}$ & $4.0 \times 10^{-3}$ & $9.0 \times 10^{-3}$ & $4.0 \times 10^{-3}$ & $9.0 \times 10^{-3}$ \\
$\mathrm{~K}_{\mathrm{z}}$ & $8.0 \times 10^{-5}$ & $2.0 \times 10^{-4}$ & $7.5 \times 10^{-4}$ & $2.5 \times 10^{-5}$ & $4.0 \times 10^{-5}$ \\
$\mathrm{~K}_{\mathrm{ho}}$ & $8.0 \times 10^{4}$ & $4.4 \times 10^{3}$ & $2.2 \times 10^{4}$ & $1.2 \times 10^{4}$ & $6.5 \times 10^{4}$ \\
$\tau_{\mathrm{W}}$ & -0.40 & 0.02 & 0.0 & 0.0 & 0.0 \\
\hline
\end{tabular}

